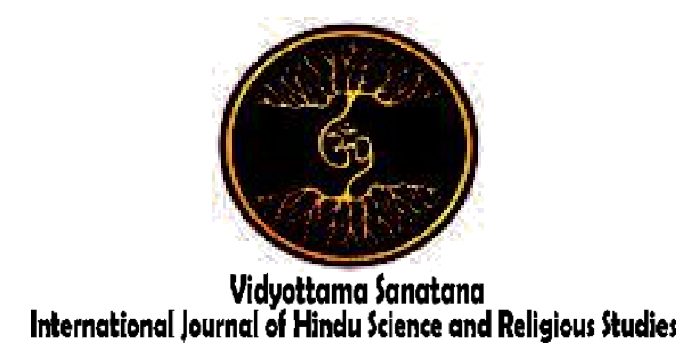

Vol. 3 No. 1 May 2019

\title{
THE REFLECTION OF ENVIRONMENTAL LAW IN LOCAL WISDOM CONCEPT OF BALINESE PEOPLE IN BALI
}

\author{
By: \\ I Nyoman Budiana, I Wayan Suderana \\ Undiknas University \\ E-mail : budiananyoman1961@gmail.com
}

\begin{tabular}{l|l|l} 
Received: March 11, 2019 & Accepted: May 4, 2019 & Published: May 31, 2019 \\
\hline
\end{tabular}

\begin{abstract}
Environment is a place for living things to live their life. The environment must be kept, maintained and developed continuously in the variety of plants existing in it. Therefore, the water source can be maintained and it can flow all the time. A simple but effective step to provide essential benefits for human life is by empowering customary people with a variety of local wisdom they have in keeping and maintaining the forest. All people who behave selfishly tend to exploit these resources, that lead to a decrease in the quality and quantity of natural resources. This selfish and free behaviors exploit natural resources, so the environment is damaged and the society as a whole suffers losses from generation to generation. Bali, supported by 1493 customary villages (pakraman), has a basic concept in managing the environment known as the Tri Hita Karana concept. All forms of activities that lead to conservation efforts and a more progressive arrangement in Balinese society will be able to be maintained well.
\end{abstract}

Keywords: Environment, forest, law, customary villages, customary people, and local wisdom.

\section{Introduction}

The phenomenon of environmental problems occurred in Indonesia in the past decade can be said very disturbing to the preservation of the natural environment. Human behavior, which for various reasons, has committed acts that lead to environmental destruction, can even threaten the sustainability and ecosystem of the environment itself. Various media have stated that in our country, there have been acts of forest encroachment and burning in 
Sumatra Island and at various points of tropical forests in Indonesia, illegal mining, uncontrolled land use change which has caused the reduced number of forests or green areas of the city and accompanied by the behavior of careless garbage disposal and the presence of illegal buildings on the banks of the river become a series of critical problems in our country.

As a result of human behavior that exploits the natural environment, it is so damaged that nature is no longer friendly with humans. The nature becomes ferocious and violent that will destroy human existence and various sources of life. It can be said if humans with their greed destroy the natural environment, then they will be destroyed by nature indiscriminately (Kompas, March 19 2019: I). In the view of environmental experts, the world has given warnings to humans indicated from the occurrence of extraordinary climate change that hits all continents in the world.

Indonesia's climate with high rainfall has resulted in flash floods and landslides occurring everywhere, such as in Sukabumi, West Java, Sentani in Papua, South Sulawesi, which has destroyed people's livelihoods, damaged the environment and claimed lives. These natural disasters do not only occur in the Asian continent, but also in various parts of the world in the United States, Australia, Europe and even Africa with the effects of drought throughout the year resulting in food insecurity. The occurrence of natural disasters that occur is a guide for humans to introspect themselves and return to live friendly with nature, regulate and manage this nature as a source of life, a place to live or die. It is also needed a synergy with the government through the enforcement of applicable laws and regulations.

Natural damage is characterized by the increasing number of deforestation. Christina Nunez, contributor to National Geographic reports that forests still cover about 30 percent of the world's land areas, but they are disappearing at an alarming rate. Between 1990 and 2016, the world lost 502,000 square miles (1.3 million square kilometers) of forest, according to the World Bank, an area larger than South Africa. Since humans have begun cutting down forests, 46 percent of trees have been felled, according to a 2015 study in the journal Nature. About 17 percent of the Amazonian rainforest has been destroyed over the past has been on the rise.

Farming, grazing of livestock, mining, and combined account drilling for more than half of all deforestation are stated. Forestry practices, wildfires and, in small parts, urbanization accounts for the rest. In Malaysia and Indonesia, the forests are cut down to make way for producing palm oil, which can be found in everything from shampoo to saltines.

Indonesia is the third largest emitter in the world due to deforestation. In order to prevent dangerous climate change, globally within a decade's deforestation needs (US Fed News Service, 2007). Hardin (1977), argues that various economic reasons often drive human behavior or various decisions taken by them both individually and in groups to use common property. Rivers, grasslands, air, and sea are the resources that can be used freely by everyone to meet their individual needs. Therefore, every person seeks and competes to exploit these natural resources to obtain the maximum personal benefits. There are people who think and behave to use these resources wisely, in which they will even do conservation and protection so that their existence is maintained. However, other people do not behave like that. As a result, most people lose motivation to maintain the viability of these resources. All people who behave selfishly in exploiting these resources, then lead to a decrease in the quality and quantity of natural resources. Selfish and free behavior of people exploits natural resources, so the environment is damaged and the community as a whole suffers losses from generation to generation (Bram, 2014: 50-51).

Based on the explanation above, the strategic steps that must be taken by the state 
are regulatively regulating and firmly enforcing the law against the highly capitalistic investors who tend to be destructive by clearing forests carelessly and doing mining that is not in accordance with the permits given, most of which are in the interior of the country's forests. If there is a strong agreement between the employers and the authorities of this country, there will be the omission with "bogus" permits so that the customary law community unit around the forest cannot do much. The forests with all the potential mining assets contained in them are dredged for capitalist wealth and on the contrary, the people only receive forest destruction due to excessive, uncontrolled and even illegal mining exploitation (Kompas, Wednesday 10 May 2017: 16). Based on data from the Central Bureau of Statistics, Bali has a forest area of 132.528.23 ha or about $23 \%$ of its total area. The forest area in Bali is threatened to decrease from year to year due to the land use change of forest areas for the construction of hotels, villas, restaurants to housing complex.

The recovery of the natural resources condition is not an easy matter. It requires a long time to thousands of years. In the short term, the remains are the condition of the damaged forest that will have an impact on the economy of the community which will cause various social vulnerabilities. Identification of the various negative effects that will be caused by capitalist behavior in the mining sector, the State through its government apparatus must be reformist, move and act in accordance with the applicable regulations and empower customary people who have more norms and ethics of local wisdom that uphold and respect forest protection and preservation.

Customary people are local communities that are responsible for environmental sustainability. One of the customary groups that still exists in Indonesia is the customary people in Bali. The customary people in Bali are incorporated into an organization called the Pakraman village. The formation of the
Pakraman village was due to an inner connection to apply Hindu teachings believed by Pakraman Village (Nyoman Satia Negara, 2016: 25767). In Hinduism, the philosophy of Tri Hita Karana is known as three causes of happiness. Tri Hita Karana as a concept that should be taken into consideration in the social life as a base for the creation of awig-awig (customary law) has a very comprehensive definition (I Gst. Pt. Bagus Suka Arjawa \& I Gst. Agung Mas Rwa Jayantiari, 2017 : 432). This philosophy teaches a good relationship between humans and God (parahyangan), humans and humans (pawongan) and humans with the environment (palemahan). Empowering customary knowledge of the customary people in Bali is an effort to create a good living environment, as an implementation of the philosophy of palemahan.

In this study, two issues will be discussed, namely the reform in the management of the environment and local wisdom of Bali in the context of the environment. The environmental management policy was initially carried out by the state, but in its development, there is a paradigm shift in environmental management carried out with the approach of the local community. The approach to the local community is carried out by exploring philosophical and religious values in the Hindu Scriptures, compiling customary laws to protect the environment and conducting religious activities in protecting the environment.

\section{Methods}

This research is a qualitative research that describes the conditions regarding the role of the customary people in Bali in protecting the environment. Resources come from primary data in the form of observations and interviews with traditional leaders in the research location. The research population is the customary people in Bali. The samples in this study are the Tenganan Pagringsingan Customary Village in Karangasem Regency, Pemuteran Village 
Gerokgak District in Buleleng Regency, and Besan Village Dawan District in Klungkung Regency. The research was conducted on the behavior of local customary people towards the environment. The secondary data in this study consist of literature related to the environment, environmental law, Hindu law, customary law, custom, and culture. Research is also conducted on the rule of law at the international level, state policy, and in customary law (awig-awig). The data obtained then were analyzed qualitatively, and descriptively presented in analytical way.

\section{Results And Discussion}

\section{Reform in Environmental Management}

The environment is a part of human life that is the source of human livelihood. Environmental problems cannot be separated from human activities. Today's environmental problems arise due to human carelessness in environmental management. The issue of environmental law in the past decade has occupied an endless place of attention and source of study at regional, national, and international levels. The environment can be said as an urgent force to regulate human life in relation to natural resource needs, while maintaining continuity and sustainability itself. The two most essential things in relation to environmental management problems, are the emergence of pollution and environmental destruction (Nurdu'a M. Arief, Nursyam B. Sudharsono, 1991: 7). The threat to the environment raises the urgency of environmental management reform.

The interests of humans to meet their life needs indirectly can damage the environment. The need for shelter can cause the conversion of agricultural land into settlements. The use of transportation equipment can cause pollution. Human behavior that destroys nature causes the unbalanced ecosystem. The unbalanced ecosystems trigger natural disasters, such as floods, landslides, extreme weather and so on. The quality of the environment (land, water and air) is declining because pollution of household waste and industrial waste is the cause of the ease of the people affected by disease (Yuli Priyanto, 2013: 41). The concerns about environmental damage triggered the United Nation as the world's largest organization to take policies to save the environment.

Environmental management reform begins with the formulation of environmental management policies. The environmental management policy at the global level is realized by drafting international agreements signed by almost all countries in the world. The Declaration of the United Nations Conference on the Human Environment, known as the Stockholm Declaration, is a declaration made at the Human Environment conference held by the United Nations in 1972. The United Nations Conference on the Human Environment, having met at Stockholm from 5 to 16 June 1972, having considered the common outlook and the common principles to inspire and guide the peoples of the world in the preservation and enhancement of the human environment. This declaration was followed by UN member countries at that time. In the statement of commitment of member states in point 7 stated "To achieve this environmental goal will demand the acceptance of responsibility by citizens and communities and by enterprises and institutions at every level, all sharing equitably in common efforts. Individuals in all walks of life as well as organizations in many fields, by their values and the sum of their actions, will shape the world environment of the future. "

Another declaration which also addresses the environment is the Rio Declaration was held in Rio de Janerio, Brazil on 3-14 June 1972. The principles contained in the Rio Declaration on environment and development regulate that natural resources can be used throughout the generations, namely by way of wise use, empowering the community to be able to enjoy together in the framework of common welfare and benefit for all citizens. The 
natural resources of the environment are managed by taking into account the concept of protection, so that welfare can be enjoyed by present and future generations, because human survival depends on the environment.

A number of environmental principles contained in the Rio Declaration include: (1) the principle of sovereignty and state responsibility which means that each country is recognized for its sovereignty in utilizing natural resources and the environment within its jurisdiction, without harming other countries or exceeding jurisdiction country; (2) the principle of justice between generations, that the use of natural and environmental resources by the present generation must not sacrifice the interests or needs of future generations. The present generations have an obligation to use natural resources in a sensible and wise manner and carry out conservation of natural resources, so that natural resources remain available in sufficient quality and quantity to be used by future generations; (3) the principle of intragenerational justice, access to utilization of natural resources must not only be monopolized by certain groups, but the natural resources should be the capital to improve the lives of the community as a whole. One example, forest tenure that was only given to a handful of people during the government of Orde Baru in Indonesia created control of the forest area only for a few people / private capital, while the customary people in the forest area become poorer and marginalized due to the loss of land for livelihood. Environmental management reform in the present era is carried out by returning to community empowerment as community forest managers in accordance with regulations that are still determined by the state; (4) the polluter pays principle, every business actor in environmental management must include the environmental costs incurred by his business into production costs. Thus, if environmental pollution occurs as an impact of the production process that can harm the community, the business actor must pay, (Rahmadi, 2015: 11-16).
The environment and all its contents are the source of human life throughout the year, from one generation to other generation. Forests are a source of living water that must be kept, maintained and continued to be developed in the variety of plants in them so that the water source can be maintained and it can flow all the time. Living things will not be able to live without water, trees, and natural environment. The humans need water. Without water, living things will die. A simple but effective step to provide essential benefits for human life is by empowering customary people with a variety of local wisdom they have in keeping and maintaining the forest.

The environment is a common property so that no one is allowed to defile it (Siti Sundari Rangkuti, 2000: 14). For this reason, environmental management must be carried out comprehensively. The environmental protection must be carried out with strong legal formulations.

Indonesian constitution or basic law, namely the 1945 Constitution of the Republic of Indonesia, in principle has provided enormous space in environmental protection. This condition causes the constitution of the Republic of Indonesia to be said as a green constitution. In principle, the green constitution constitutes the normalization of environmental legal norms into the constitution by increasing the degree of norms of environmental protection to the level of the constitution. Thus, the importance of the principles of environmentally sustainable development and protection of the environment has a strong foothold in legislation. On that basis, the green constitution then introduces terminology and concepts called ecocracy which emphasizes the importance of environmental sovereignity (I Putu Sastra Wibawa, 2016: 43).

The state basically has the duty to formulate environmental policies and enforce laws against perpetrators of environmental crimes. The country's tasks need to be balanced with the participation of the community in managing the 
environment. One component of the community in question is the customary people. Their involvement in managing the environment is based on the provisions in Article $18 \mathrm{~B}$ of the Constitution of the Republic of Indonesia which states:

(1) The State shall recognize and respect entities of regional administration that possess a specificity or a distinctiveness that are to be regulated by law.

(2) The State shall recognize and respect, to be regulated by law, the homogeneity of societies with customary law along with their traditional rights for as long as they remain in existence and in agreement with society development and with the principle of the Unitary State of the Republic of Indonesia.

Pakraman village is a customary law community that is still alive and in accordance with community development. Pakraman village as a customary village in Bali has a duty together with the government to carry out development in all fields, especially in the fields of religion, culture and society. In addition, Pakraman village has the task of fostering and developing Balinese cultural values in order to enrich, preserve and develop national culture in general and regional culture in particular, based on paros, sagilik saguluk, salunglung sabayantaka (consensus meeting) (I Nyoman Sirtha, 2008 : 14). Current environmental management reform requires the involvement of customary people by exploring the local wisdom that is in it.

Customary villages basically function to regulate the lives of the residents of the village in an effort to realize the welfare and happiness of the villagers called Moksa and Jagadhita, which is in line with the goals of Hinduism namely Morksartham Jagadhita ya ca iti Dharma (I Wayan Surpha, 2004: 24). In the context of customary law, prosperity and happiness will occur if the mini-nature is balanced. Natural balance is certainly related to efforts to protect the environment from damage and pollution.

\section{Balinese Local Wisdom in the Context of the Environment}

Bali, supported by 1493 customary villages (pakraman), has a basic concept in managing the environment known as Tri Hita Karana concept. The basic philosophical concept of Balinese society emphasizes the principle of harmony, the balance between three (3) main elements in life, namely the relationship of harmony between humans and God (Ida Hyang Widhi), which is called the parahyangan element, a relationship between humans and humans called pawongan and relationships harmony between humans and the environment called the palemahan element. The relationship that is harmoniously interwoven in the beliefs of the Balinese people will be able to provide happiness and prosperity together. This concept in social institutions in Bali is expressed in the form of awig-awig (Balinese customary law in the form of written), which functions to regulate customary people in all aspects of life that are related to customary, culture and religious rituals aspects. Especially in the context of palemahan, the existence of the awig-awig of pekraman village in Bali regulates: (1) the relationship of the customary villagers (krama) with their pekarang desa (village environment or PKD); (2) relationship of the villagers (krama) with the tanah ayahan desa (village land or AyDS); (3) relationship of the villagers (krama) with pelaba pura (temple property) and (4) relationship between villagers (krama) and other environments such as ricefields, moorings, forests, rivers, and roads to keep them clean and beautiful so that there is no the impression of slum, (Ardana, 2007: 8-10).

The environment of the customary house is arranged with the concept of tri mandala, namely the concept of spatial / zoning in the home yard which is divided into three parts, namely the utama, madya, and kanista mandala. The utama mandala (main zone) with the northeast position is used for family sanctuaries like pura or sanggah (temple), in the madya mandala 
(middle zone) is for building houses, used for activities in the family and in the kanista mandala is for livestock pens, family bathrooms or profane activities (Gorda, 1999: 37-41; Ardana, 20017: 60-62). The same arrangement is also applied in the construction of pura (temple), where the zoning arrangement is divided into utamaning mandala or jeroan, madyaning mandala or jaba tengah and kanistaning mandala or jaba sisi.

The concept of the Tri Hita Karana philosophy is a unit that is not separated. Institutions that organize and regulate so that the life of Balinese people can run well are arranged by customary villages with awigawig devices / provisions of customary institutions that are very effective. Based on the author's observation to the field, it can be stated that several examples of the awig-awig customary village owned in the context of environmental preservation namely Awigawig Adat Tenganan Pagringsingan Village as one of Baliage villages in Karangasem Regency. It has customary rules that are very effective in protecting and regulating the use of the natural forest resources in the hills surrounding the village within the framework of preserving forests, water and improving the welfare of local village communities (Results of an interview by Mr Sadra, BA, February 8, 2019). Likewise in Pemuteran Village, Gerokgak Subdistrict, Buleleng Regency, including West Bali region also has awig-awig which is very effective in regulating and protecting the sea overgrown with coral reefs, because the coral reefs are a place for living and developing marine biota including fish as the source of livelihood by the local community. Along with efforts to preserve marine biota, the zoning has finally developed into a very interesting coral reef tour. Besides, Besan Village, Dawan Subdistrict, Klungkung Regency also has a customary practice in the form of uger-uger (rules) to protect coconut trees that grow in the moor in the village area, because coconuts are cultivated to produce tuak (palm wine) which is processed into brown sugar as a home industry, etc.
Based on the ecological or environmental context, Balinese people have come to know the harmony between the bhuana agung (macrocosm) and the bhuana alit (microcosm) and the Balinese always see themselves as the microcosm must align themselves with the macrocosm (universe). The universe as a place of residence zoning needs to be preserved and balanced so that humans obtain life welfare, both material and spiritual, (Ardana, 2007: 60).

To maintain the harmony of the relationship between the macrocosm and the microcosm, in the belief of Hindus, a ritual called bhuta yadnya or caru is held. This ceremony is a sacred sacrifice or ritual that is carried out all times to maintain the balance of life. One of them is the mapulang pakelem ceremony (a ritual ceremony in which the offerings are given by throwing them away to the mountain or sea). There are series of other ceremonies that have meaning in the context of environmental preservation carried out by the Balinese people in harmonizing themselves with nature, namely the ceremony of tumpek bubuh or tumpek pengatag and tumpek kandang. The tumpek bubuh ceremony was held on the day of Saniscara Kliwon Wuku Wariga, exactly twenty five days before the celebration of the holy day of Galungan, as a form of offering and gratitude to Hyang Widhi in his manifestation as Dewa Sangkara who creates nurturing plants. Whereas the ceremony of tumpek kandang or tumpek uye is a religious ritual to give a sense of devotion and gratitude to Hyang Widhi who creates animals or pets that are very useful for human life like to help the human's work in plowing the fields and fulfill the necessities of life as a source of protein for human. (Ardana, 2007: 62: Udayana, 2008: 8-10).

Moreover, the use of animals for ceremonial purposes can be seen from the book of Manawadharmasastra, V.42, which explains that God (Hyang Widhi) creates animals and plants for the good of the Earth, "eswarthesu pacunhimsan weda, 
tattwarthawid dwijah, atmanam ca pacun caiwa ga, mayatyutanamgatin,". It means to slaughter an animal with the above purposes, causing the animal enters a very happy state. Based on the description, it can be seen that the use of wewalungan (animals) in carrying out the yadnya ceremony, especially the bhuta yadnya "mecaru" contains sanctification for the balance of the macrocosm and microcosm, (LPM Unud, 2008: 15).

Another famous local wisdom in Bali reaching overseas which is also important as environmental conservation and development is the Subak irrigation system. In essence, the subak irrigation system is as a manifestation of the philosophy of Tri Hita Karana. Subak can be divided into several sub-systems, namely: (a) cultural subsystem, reflected in the mindset of irrigation water management carried out on the basis of harmony and togetherness. Water resources are highly respected and considered to have high value as a gift and creation of God Almighty. Therefore, Subak held a special ceremony to respect the existence of water for agriculture, which was called the mendak toya ceremony (picking up the holy water). Hinduism highly respects water, all religious ceremonies are inseparable from water. Therefore, Hinduism is also known as the Tirta religion. The Balinese Hindu community strongly believes that water is a symbol or embodiment of Lord Vishnu and Lord Vishnu is a manifestation of God Almighty believed to be the preserver of life in the world; (b) social sub-systems, reflected in the existence of subak organizations that are tailored to the interests of the local community and adapted to the objectives that want to be achieved. The organizational structure of Subak is different from one another depending on the extent of the region being managed, the availability of irrigation water, and the activities that must be carried out by the subak concerned. Subak also has awig-awig which is made based on the concept of parahyangan, and this provision is highly respected by its members.
Substantially, the awig-awig rule regulates matters related to various efforts so that the traditional subak organization can run in accordance with its objectives, namely managing an irrigation system based on a spirit of harmony and togetherness. Some concepts related to the subak system in Bali, namely empelan (dam), Tembuku both in the form of numbak or ngerirun and there are also aungan (tunnels), telabah, pengalapan and pengutangan made jointly by the subak krama (member). The head as subak leader is known as pekaseh; (c) artifact / material sub-system, reflected by the availability of irrigation network facilities that are commensurate with the needs of the subak organization, which allows water to be distributed fairly, and the irrigation process can be carried out quickly, (Windia, 2006: 13-18) .

The main activities in the subak irrigation system include irrigation, planting patterns and ceremonies. Arrangements for water distribution are carried out on the basis of consensus agreements to achieve justice among the subak krama itself by distributing water proportionally based on land area of rice fields or by other agreements. Supervision of water distribution is carried out strictly, especially in small water situations, to prevent water theft. The implementation of supervision and water distribution arrangements fairly allows the sub-district staff to carry out an orderly planting pattern. The planting patterns in the subak irrigation system in Bali are known to be two systems, namely tulak sumur and kerta masa. In the tulak sumur system, the implementation of cropping patterns is carried out irregularly.

In the ricefields, there are subak krama who are cultivating land, some have planted rice and even the paddy has turned yellow, while the kerta masa (periodic) system, carrying out the cropping patterns simultaneously. They begin to cultivate the land until plant rice done simultaneously so that the rice plants look green and even yellowing simultaneously when the harvest 
day arrives. Furthermore, in the aspect of ceremonies, various types of ceremonies are carried out both individually and in ceremonies for the common interest. There are various types of ceremonial activities such as the ngendak ceremony when it just starts to plow, the ngurit ceremony when it starts sowing seeds, the nandur ceremony when it starts planting rice, the biyukukung ceremony when the rice begins to bear fruit, the ngulapain ceremony when harvesting rice and the mantenin ceremony after the rice has been stored in the barn. While the ceremonies for the common interest such as the ceremony of mendak toya, activities to meet the water and nangluk merana when rice plants are attacked by pests, (Sirtha, 2008: 54-56).

As the last manifestation of local wisdom in the context of the environment, the author describes the celebration of the Holy Day of Nyepi. Nyepi is a Hindu ritual activity that is celebrated once a year in the calculation of the year of Caka. The year of Caka has a difference of 78 years with the year of Christ. In this Nyepi celebration, there is a meaning that all Hindus respect the universe by resting even in only one full day. The world is rested from pollution and it can save energy by not using fire, electricity, internet and vice versa. It is used to regulate gratitude to Hyang Widhi for all the creation and pleasure given to all people. Nyepi in a more contemporary context, in the use of chemical energy within the framework of the enjoyment of human life, it is very relevant to be rested for certain periods. The relevance can be seen from the belief in the Nyepi celebration in the form of Amati Gni, controlling the passions which are marked by symbol not lighting fires; Amati Karya, not working hard that raises a loud noise; Amati Lelungan, not traveling and Amati Lelanguan, not carrying out entertainment activities, (Wartam, March 2016 Edition).

\section{Conclusion}

Environment management reform requires comprehensive efforts from the state in formulating policies in the environmental field based on agreed international commitments and involving the community in forest management based on their traditional values. The protection in environmental management has the same meaning as Balinese local wisdom that emphasizes the concept of harmony and balance in the framework of preserving natural resources. All forms of activities that lead to more progressive preservation and structuring efforts in Balinese society will be able to be maintained properly, because local wisdom is bound by a traditional institution that has universal values and others are bound by a religious ritual that is believed providing welfare.

Deviant behavior such as environmental crimes in the form of environmental destruction, such as the forest burning, illegal logging, and excessive exploitation of the mine that occurred in the decade after the recent reforms, requires strict and consistent enforcement of the environmental criminal sanctions. In addition, a commitment is needed to empower customary people in the forest area to maintain, keep and supervise their sustainability so that environmental resources can still benefit the improvement of community welfare and as a healthy and proper environmental heritage to the next generation. The customary people in Bali have made various efforts to protect the environment based on the sacred Hindu books. The actions ordered and those prohibited related to the environment are regulated in awig-awig.

\section{References}

Ardana, I Gusti Gede. 2007. Pemberdayaan Kearifan Lokal Masyarakat Bali Dalam Menghadapi Budaya Global, Denpasar: Pustaka Tarukan Agung.

Bram, Deni. 2014. Politik Hukum Pengelolaan Lingkungan Hidup, Malang: Setara Press. 
Christina Nunez, February 7 , 2019 , "Climate 101 : deforestation", https://www.nationalgeographic.com/e nvironment/globalwarming/deforestation/

Gorda, I Gusti Ngurah. 1999. Manajemen dan Kepemimpinan Desa Adat di Propinsi Bali, Denpasar: Widya Griya Gematama.

Hardin, Garret. 1997. The Tragedy of the Commons (dalam Garret Hardin dan John Baden (ed), 1977, Managing the Commons), Library of Congres.

LPM Unud. 2008. Satwa Upakara (Sarana Perlengkapan Upacara Agama Hindu), Denpasar: Universitas Udayana.

Nurdu'a M. Arief, Nursyam B. Sudharsono.1991. Aspek Hukum Penyelesaian Masalah Pencemaran dan Perusakan Lingkungan Hidup. Semarang: Satya Wacana.

Prayitno, Y., Djati, M. S., Soemarno, S., \& Fanani, Z. (2013). Pendidikan Berperspektif Lingkungan Menuju Pembangunan

Berkelanjutan. WACANA, Jurnal Sosial dan Humaniora, 16(1), 41-51.

Rahmadi, Takdir. 2015. Hukum Lingkungan di Indonesia, Jakarta: Raja Grafindo Persada.

rjawa, I. B. S., \& Jayantiari, I. M. R. (2017). Democratic values in Balinese traditional society: Analysis of the making and the content of Desa Pakraman's awig-awig. Masyarakat, Kebudayaan dan Politik, 30(4), 428436.

Satia Negara, Nyoman. 2016. The recognition and respect to the customary law people in the village government system in Bali. International Journal of Current Research 08 (01): 25764-25769.
Sirtha, I Nyoman. 2008. Aspek Hukum Dalam Konflik Hukum Adat di Bali, Denpasar: Udayana University Press.

Sirtha, I Nyoman. 2008. Subak (Konsep Pertanian Religius), Surabaya: Paramita.

Siti Sundari Rangkuti. 2000. Hukum Lingkungan dan Kebijakan Lingkungan Nasional Edisi Kedua. Surabaya: Airlanggga University Press.

Surpha, I Wayan. 2004. Eksistensi Desa Adat dan Desa Dinas di Bali. Denpasar: Pustaka Bali Post.

Udayana, I Dewa Gede Alit. 2008. Tumpek Kandang (Kearifan Lokal Bali untuk Pelestarian dan Pengembangan Sumber Daya Ternak, Denpasar: Pustaka Bali Post.

US Fed News Service, Including US State News ; Washington, D.C. [Washington, D.C], 04 Dec 2007. Greenpeace Launches Landmark Proposal for Reducing Tropical Deforestation at Bali Climate Talks.

Wartam. 2016. Majalah "Hari Nyepi (Metamorfose Jati Diri)", Denpasar: Mabhakti.

Wibawa, I. P. S. (2016). Politik Hukum Perlindungan dan Pengelolaan Lingkungan Menuju Ekokrasi Indonesia. Kanun: Jurnal Ilmu Hukum, 18(1), 51-68.

Windia, I Wayan. 2006. Transformasi Irigasi Subak Yang Berlandaskan Tri Hita Karana, Denpasar: Pustaka Bali Post. 